\title{
Competition for FDI and profit shifting: On the effects of subsidies and tax breaks*
}

\author{
Oscar AMERIGHI ${ }^{\dagger}$ Giuseppe DE FEO
}

October 2013

\begin{abstract}
We investigate competition for FDI within a region when a foreign multinational firm can profitably exploit differences in statutory corporate tax rates by shifting taxable profits to lower-tax jurisdictions. In such framework we show that targeted tax competition may lead to higher welfare for the region as a whole than lump-sum subsidies when the difference in statutory corporate tax rates and/or their average is high enough. Tax competition is also preferable from an efficiency point of view (overall surplus) by changing the firm's investment decision when profit shifting motivations induce the firm to locate in the (before tax) least profitable country.

Keywords: Policy competition for FDI; Profit shifting; Tax discrimination
\end{abstract}

JEL Classification: H25; H26; H32; H73; F23

${ }^{*}$ We wish to thank Giacomo Calzolari, Ronald B. Davies, Rodolphe Desbordes, Marina Di Giacomo, Jean Hindriks, Giorgia Maffini, Diego Piacentino, Pierre M. Picard, Federico Revelli, Francesca SannaRandaccio, Jacques Thisse, Hylke Vandenbussche, Ian Wooton, as well as seminar participants at the University of Bologna, at the University of Strathclyde, and at the $X X V$ SIEP Annual Conference for valuable comments and suggestions.

${ }^{\dagger}$ ENEA, Lungotevere Thaon di Revel 76, I-00196 Rome, Italy; CORE, Université catholique de Louvain, Belgium; and Dipartimento di Scienze Economiche, Università di Bologna, Italy. E-mail: oscar.amerighi@enea.it

${ }^{\ddagger}$ Department of Economics, University of Strathclyde, Sir William Duncan Building, 130 Rottenrow, Glasgow G4 0GE, UK; and Dipartimento di Scienze Economiche e Aziendali, Università degli Studi di Pavia. E-mail: giuseppe.defeo@strath.ac.uk 


\section{Introduction}

In recent years governments throughout the world - at the national or sub-national level - have designed and implemented policies with the aim of attracting foreign direct investments (FDI). Competition for foreign investments in major production facilities mostly occurs at an intra-regional level, i.e., between countries belonging to the same geographic or economic area (e.g., Latin America, South-East Asia, Central and Eastern Europe) or between regions within the same country. The incentives offered to foreign investors often consist in corporate tax reductions, tax breaks, tax holidays, investment tax allowances, or other kinds of specific tax concessions. For instance, during the 1990s, Brazil has experienced several cases of inter-regional competition for FDI in the automobile sector, and fiscal incentives typically included state and local tax holidays (for as long as ten years) in addition to tax breaks on imported materials. In Western Europe, over the last 20 years, Ireland has successfully employed incentive packages - including a considerable lowering of corporate taxes - to attract FDI. In 1998 the Czech government, after having lost potential FDI inflows in previous years in favor of neighboring countries - like Hungary and Poland - eventually approved a package of incentives including corporate tax relief for ten years for newly-established companies in the country. ${ }^{1}$ An example of the way national governments might have to deal with big foreign investors is represented by the relocation from Austria to Germany of Sandoz, the generics subsidiary of Switzerland's drugs maker Novartis, in 2005. This was the eventual outcome of the company's unconcealed attempt to exploit "latent tax competition between Germany, Austria and Switzerland" ("Sandoz seeks more taxfriendly location", Financial Times, April 14, 2005).

The relationship between corporate taxation and the location of multinational firms is an important policy issue and there is general agreement on the idea that national corporate tax systems should not discriminate between taxation of purely domestic and of multinational firms. The so-called non-discrimination principle has been recommended by both the European Union and the OECD (European Communities, 1992, 1998; OECD, 1998) to counter harmful tax competition between governments. In this sense, one of the major attempts worldwide to limit policy competition for FDI is represented by State Aid Control in the EU. If a Member State lowers the tax rate or grants other types of tax advantages only to certain sectors or to certain types of firms (e.g., coordination centers for multinational firms in Belgium) or to enterprises located in a certain area within the Member State, this would constitute State aid. A proper implementation of the EU State Aid Control system should thus prevent countries from offering subsidies in order to attract foreign investors. In spite of that, Vandenbussche and Tan (2005) provide empirical evidence of a more favorable tax treatment for foreign multinationals compared to similar domestic firms in Belgium. As their results

\footnotetext{
${ }^{1}$ All of these examples are taken from Charlton (2003). For an overview of the policy-competitionfor-FDI issue, see Oman (2001).
} 
are not driven by profit shifting issues, there should exist other fiscal incentives besides cross-country tax differentials to justify lower tax payments by multinational firms. A possible interpretation is that the country offers targeted fiscal incentives (in terms of, e.g., under-the-counter subsidies) to foreign investors.

The empirical research about taxation and foreign investments focuses mainly on how taxes affect the volume and distribution of FDI. ${ }^{2}$ But there are also contributions that analyze more specifically the impact of corporate taxation on firms' location decisions. ${ }^{3}$ Devereux and Griffith (1998) find a significant effect of effective average tax rates on the location choice of subsidiaries of U.S. firms within Europe. On the other hand, Buettner and Ruf (2007) show that statutory tax rates are at least as important as labor cost differences for explaining the observed location decisions of German multinationals. Moreover, the statutory tax rate is found to have a considerably stronger predictive power than the effective average tax rate, and this "might indicate that multinationals take account of profit-shifting opportunities in the choice of location of their subsidiaries" (Buettner and Ruf, 2007, p. 162).

Our paper investigates the effects of policy competition for FDI when the foreign multinational can strategically react to differences in statutory corporate tax rates and shift taxable profits to lower-tax jurisdictions. In particular, we aim at understanding whether it can be welfare-improving for the region as a whole that countries compete against each other by offering further tax incentives when their national corporate tax systems already give the multinational some opportunities to minimize its worldwide tax liabilities.

Our main contribution is to show that, in the presence of profit shifting, targeted tax competition (i.e. tax breaks) always induces the efficient location choice; i.e., the one which maximises the sum of regional welfare and firm's profits. On the contrary subsidy competition cannot completely offset the distortion created by the difference in statutory tax rates. Moreover, targeted tax competition might be preferable - in terms of regional welfare - to lump-sum subsidies as a policy instrument to attract FDI. This is more likely to be true when the statutory tax rate difference within the region and/or the average tax rate prevailing in the region are high. Such a result has important policy implications for, e.g., the European Union, an area characterized by both high tax levels and differentials. Indeed, it challenges the propriety of the non-discrimination principle that, by restricting the policy instrument set at the governments' disposal to attract FDI, induces countries to compete in a way that might end up lowering regional welfare. $^{4}$

\footnotetext{
${ }^{2}$ See, e.g., De Mooij and Ederveen (2003) for a survey.

${ }^{3}$ At the sub-national level, Bartik (1985) shows that the corporate tax rate has a significant impact on business location decisions within the U.S. Subsequent empirical studies on interregional location decisions have confirmed this result. See Phillipps and Goss (1995) for a survey.

${ }^{4}$ Devereux and Loretz (2012) have recently reviewed the empirical literature about competition in source-based taxes on corporate income. They have found that tax competition appears to be strongest in the EU with a relevant impetus to downward competition provided by the accession of new small
} 
The present work is closely related and contributes to two main strands of research: the literature about policy competition for FDI that has developed from the seminal contribution by Haufler and Wooton $(1999) ;{ }^{5}$ and the literature discussing restrictions to targeted tax competition (see, e.g., Janeba and Peters, 1999; Keen, 2001; Janeba and Smart, 2003; Bucovetsky and Haufler, 2008) or the effects of tax coordination between countries (see, e.g., Huizinga and Nielsen, 2002, and Haufler and Wooton, 2006). The literature about policy competition for FDI typically addresses the questions as to which one of two asymmetric countries wins the FDI competition and whether the winner, in equilibrium, taxes or subsidizes the foreign firm. On the other hand, the contributions on targeted tax competition usually build upon models which take into account both mobile and immobile tax bases, and, depending on their elasticities, show that competition may or may not be beneficial in terms of tax revenues. However, none of these papers takes into account the possibility that multinational firms consider profist-shifting opportunities when choosing the location of their subsidiaries, and most of them lack a regional welfare analysis of policy competition. ${ }^{6}$

The rest of the paper is organized as follows. In Section 2, we present and justify the main assumptions and the structure of the theoretical framework we use to analyze policy competition for FDI. In Section 3, we analyze a set-up where no profit shifting takes place and discuss the welfare implications of policy competition. Section 4 introduces the possibility of profit shifting in response to statutory tax rate differentials. We then perform an analysis that parallels that of the previous Section and compare the results. Finally, Section 5 summarizes the main conclusions emerging from this work.

\section{The model}

We develop a model in which two potential host countries, $A$ and $B$, belonging to the same region (be it a political, economic or geographical area) compete between them to attract investments by a foreign-owned firm from a third-country outside the region we call the latter country $F$ and we can think of it as the rest of the world. A typical example may be the case of multinational firm which, once located in the region, supplies some final good to the consumers of the whole area. To this end, it must establish a production facility in either $A$ or $B .^{7}$

Member States. See also Revelli (2005) for a review of the empirical research on strategic tax interaction between governments.

${ }^{5}$ See, e.g., Bjorvatn and Eckel (2006) and Ferrett and Wooton (2010a,b).

${ }^{6}$ Fumagalli (2003) investigates the effects on regional welfare of subsidy competition for FDI when the location of the multinational firm exerts a positive externality in terms of a technological spillover to local firms.

${ }^{7}$ Exports of the final good from country $F$ are not a viable option for the foreign firm if we assume that trade costs between country $F$ and the region are prohibitively high. On the other hand, assuming that the costs for intra-regional trade are low enough rules out the possibility that duplicating a costly investment, i.e. setting up two production plants, one in $A$ and one in $B$, is a profitable strategy for the 
We want to investigate the effects of policy competition for FDI when the foreign multinational can strategically react to differences in corporate tax rates and shift taxable profits to lower-tax jurisdictions. Hence, we represent policy competition as a three-stage game with complete information characterized by the following sequence of decisions: ${ }^{8}$

- In stage 1 , the governments of countries $A$ and $B$ simultaneously and irreversibly post bids to attract the foreign investor.

- In stage 2 , the foreign multinational decides whether to establish its production plant in $A$ or in $B$, and realizes profits by serving the regional market.

- In stage 3 , the foreign multinational chooses the amount of profits to declare to the tax authorities of the countries where it operates, that is either $A$ or $B$, and $F$.

We solve our three-stage game by backward induction to find its subgame perfect equilibrium in pure strategies. We then compare two alternative forms of policy competition for FDI with the no policy competition scenario where the multinational firm faces exogenous statutory corporate profit tax rates. Under lump-sum subsidy competition, we let the two countries compete for FDI by offering lump-sum subsidies $S_{i}(i=A, B)$ to the foreign multinational, that still faces exogenous statutory tax rates. Under targeted tax competition, instead, governments are allowed to tax discriminate between firms. In particular, country $i$ can choose an ad hoc corporate tax rate $\tau_{i} \in[0,1](i=A, B)$ that it will apply just to the profits the multinational firm declares there. The main difference between subsidy and tax competition is that subsidies are assumed to be lump-sum, while the tax competition is about setting an ad hoc tax rate on the declared profits of the firm. Examples of the first type of policy are the cash grants for high-tech firms used in Chile, or the site preparation grant by the Brazilian State of Rio Grande for the General Motors investment, while the corporate tax relief for new investments which are used by several countries (India, Malaysia, Czech Republic, just to mention few cases) are example of the second type of policy.

We first analyze a situation where declared profits in one country coincide with those actually realized there. We then discuss the impact of profit shifting opportunities by allowing for profit misdeclaration when corporate tax rates differ across countries.

\footnotetext{
foreign firm.

${ }^{8}$ The game structure is similar to the one used by Bernheim and Whinston (1998) to analyze exclusive dealing contracts. Differently from their contribution, we restrict the strategy set of the agent (the foreign multinational) to the choice of only one principal (the country where it will invest). In addition, we assume complete information for all the agents. A possible extension to our paper could treat the relative profitability of alternative locations and/or the value of outside options as private information of the multinational firm.
} 


\subsection{Profits of the multinational firm}

We denote by $\Pi_{i}(i=A, B)$ the before-tax or operating profits that the multinational firm realizes when it locates its production plant in country $i$. They represent the profits that the firm earns by selling the final good to consumers of the whole region and they may include any kind of fixed and/or variable production costs.

The before-tax profitability of locating in one of the two countries is not the same from the foreign firm's perspective. For instance, one country might represent a cheaper production location than the other or it might ensure an easier access to specific inputs (e.g., high-skilled workers, raw materials, etc.) for the foreign firm. Similarly, in the presence of intra-regional trade costs, differences in country - notably, market - size might be relevant for the firm's location decision. In what follows, we will assume, without loss of generality, that country $B$ is the best location for the firm's production plant in the absence of tax motivations, i.e. country $B$ benefits from a location advantage over country $A$ :

Assumption $1 \Pi_{B}>\Pi_{A}>0$

Assumption 1 further implies that the foreign firm has always an incentive to invest in the region regardless of any tax incentive offered by the two countries. In such a sense, $\Pi_{A}$ and $\Pi_{B}$ may be considered as the extra-profits that the foreign multinational obtains by locating in the region with respect to some outside option from investing somewhere else.

Fiscal considerations, however, might play a role in driving the investment decision of the foreign multinational. As it is common in the literature, we assume that international corporate taxation follows the source principle, so that profits are taxed where they are generated. ${ }^{9}$ To this end, we denote by $t_{A}, t_{B} \in[0,1]$ the statutory corporate tax rates set by countries $A$ and $B$, respectively. Similarly, we let country $F$ tax the profits declared by the multinational firm in its residence country at the rate $t_{F} \in[0,1]$. These are the legally imposed rates of corporate taxation which, in principle, should be applied in order to determine tax liabilities of both domestic and foreign firms operating within one country's national borders. To make the analysis of policy competition for FDI interesting, we assume that country $B$ has a fiscal disadvantage relative to country $A:^{10}$

\section{Assumption $2 t_{B}>t_{A}$}

In this way, the foreign multinational always faces a trade-off when deciding in which country to invest and policy competition might play a role in driving the FDI decision.

We do not make any other specific assumption about the relationship between the three countries' statutory tax rates. We want to stress, however, that any tax rate

\footnotetext{
${ }^{9}$ Keen (1993), among others, argues that the effective taxation of multinational firms is source-based, even though tax codes may stipulate differently.

${ }^{10}$ It should be clear that if country $B$ enjoys both a location and a fiscal advantage over country $A$, policy competition cannot turn the latter into a more attractive location for FDI.
} 
differential creates profit shifting opportunities for the multinational firm. In fact, firms engaging in horizontal (or vertical) FDI own fiscal entities at different locations and can shift profits from high-tax to low-tax jurisdictions in many different ways: for instance, by manipulating transfer prices on intra-firm traded goods; or by allocating high-interest debt to high-tax jurisdictions; or even by re-assigning common expenses to affiliates in high-tax countries. All of these techniques allow a multinational firm to minimize its worldwide tax bill while imposing significant accounting and other costs on the firm itself. $^{11}$

To account for the possibility of profit misdeclaration, we denote by $\pi_{i}$ and $\pi_{F}$ the amount of profits that the multinational firm declares to country $i$ and country $F$ tax authorities, respectively, and we postulate that they may differ from the profits that the firm actually realizes at each location, denoted by $\Pi_{i}$ and $\Pi_{F}$. Our argument is that the firm has to declare the totality of its worldwide profits, i.e. $\pi_{i}+\pi_{F}=\Pi_{i}+\Pi_{F}$, but it may choose how to allocate taxable profits across the countries where it operates in an attempt to minimize its overall tax liabilities. Hence, declared and realized profits in one country need not coincide. In particular, the amount of profits that the firm shifts from country $i$ to country $F$ (or the other way around) in response to cross-country tax rate differentials is given by $\pi_{s} \equiv \pi_{i}-\Pi_{i}=\Pi_{F}-\pi_{F}$. It is evident that, if the firm wishes to declare more profits than those actually realized in country $i\left(\pi_{i}>\Pi_{i}\right)$, it has to declare less profits than those actually realized in its residence country $\left(\pi_{F}<\Pi_{F}\right)$.

Profit shifting entails some costs, which may involve expected fines or hiring tax experts in order to conceal any profit misdeclaration from tax authorities. We assume these costs to be increasing in the difference between realized and declared profits, that is in the amount of profits that the firm reallocates across the two countries, and we let them also depend on an exogenous parameter, $\gamma \geq 0$, which might reflect governments' intensity in controlling tax avoidance by multinational firms, or, alternatively, international tax base mobility. More specifically, the costs for profit shifting in either

\footnotetext{
${ }^{11}$ The existence of profit shifting - notably, from the United States to low-tax countries (or tax havens) - is widely documented. See Hines (1999) for a comprehensive survey of the empirical literature on this issue. Bartelsman and Beetsma (2003) have provided evidence that profit shifting opportunities exist among OECD countries as well. More recently, Heckemeyer and Overesch (2013) have conducted a meta-analysis of the empirical literature about the profit-shifting behavior of multinational firms in both public economics and accounting research. They find a substantial response of profit measures to international tax rate differentials (i.e., a tax semi-elasticity of subsidiary pre-tax profits of about 0.8 ). Moreover, their results suggest that transfer pricing and licensing - rather than financial planning - are the dominant profit-shifting channels.
} 
direction, i.e., out of (into) country $i$ into (out of) country $F$, are given by: ${ }^{12}$

$$
C\left(\gamma, \Pi_{i}-\pi_{i}\right)=\frac{\gamma}{2}\left(\Pi_{i}-\pi_{i}\right)^{2}, i=A, B .
$$

The objective of the multinational firm is to pick the location which maximizes its after-tax profits. Since it evaluates both profit shifting opportunities and possible fiscal incentives when taking such a decision, its after-tax profits from investing in country $i$ can be written as follows:

$$
\Pi^{i}=\Pi_{i}+\Pi_{F}-t_{i} \pi_{i}-t_{F}\left(\Pi_{i}+\Pi_{F}-\pi_{i}\right)-\frac{\gamma}{2}\left(\Pi_{i}-\pi_{i}\right)^{2}+S_{i}, \quad i=A, B
$$

where

- $S_{i}=0$ under no subsidy competition;

- $S_{i}>0$ under lump-sum subsidy competition (for given statutory tax rates);

- $t_{i}=\tau_{i}$ and $S_{i}=0$ under targeted tax competition.

\subsection{Welfare and overall efficiency}

We assume that countries $A$ and $B$ have Leviathan governments interested in maximizing tax revenues and deciding their fiscal policies to attract FDI independently. In particular, the welfare function maximized by the government of country $i$ when investment takes place in country $j(i, j=A, B)$ corresponds to net tax revenues and it takes the following form

$$
W_{j}^{i}= \begin{cases}T R_{i}-S_{i} & \text { if } i=j \\ 0 & \text { otherwise }\end{cases}
$$

where $T R_{i}=t_{i} \pi_{i} \geq 0$ denotes the revenue arising from taxation of the profits declared by the multinational firm to country $i$ 's tax authorities, and $S_{i}$ corresponds to the lumpsum subsidy paid to attract FDI under subsidy competition.

When we analyse the efficiency of the equilibria we use the sum of regional welfare and foreign firm's profits as a measure of the overall surplus generated, that is equal to pre-tax profits. Therefore, we identify the efficient location choice as the one that maximises overall surplus which is, by Assumption 1, to invest in country $B$.

\footnotetext{
${ }^{12}$ The profit-shifting cost function we use here is standard in the literature. See, e.g., Swenson (2001), Kind et al. (2005), Peralta et al. (2006), and Amerighi (2008). As it shall become clear below, such a cost specification leads to the result that tax motivations make the multinational firm shift the same amount of profits irrespective of the level of realized profits. If we assumed, instead, following Hines and Rice (1994) and Huizinga and Laeven (2007), that the costs of profit shifting are proportional to the ratio of shifted to realized profits, the amount of profit shifting would depend on the level of the profits realized in the higher-tax country. This, however, does not seem to provide additional insights into the issue we are interested in. Moreover, it has a major drawback in that we would need to analyze different tax scenarios depending on how $t_{A}$ and $t_{B}$ compare to $t_{F}$ and between them.
} 


\section{$3 \quad$ No profit shifting}

We first analyze the basic set-up where we assume that the foreign multinational cannot reallocate taxable profits in response to cross-country tax differentials. Hence, our model reduces to a two-stage game where the profits declared to one country's tax authorities coincide with those earned by operating there, i.e., $\pi_{i}=\Pi_{i}, i=A, B, F$.

In the absence of policy competition for FDI between countries $A$ and $B$, the foreign multinational invests in country $B$ if the latter's location advantage outweighs its fiscal disadvantage with respect to country $A$. In particular, FDI goes to country $B$ as long as the following condition holds:

$$
\left(1-t_{B}\right) \Pi_{B}>\left(1-t_{A}\right) \Pi_{A}
$$

Otherwise, tax savings motivations make the foreign firm choose to invest in the least profitable (before-taxes) location.

We now investigate how policy competition affects the investment decision of the multinational. To this end, we assume that the location advantage of country $B$ cannot be so large - relative to its fiscal disadvantage - that this country attracts FDI by levying a lump-sum tax on the foreign firm's profits while keeping its corporate tax rate $t_{B}$ constant:

Assumption $3\left(1-t_{B}\right) \Pi_{B}<\Pi_{A}$

The latter is a sufficient condition to have a positive subsidy paid or a lower tax rate charged by country $B$ to the foreign firm in the absence of profit shifting. Similarly, assumptions 1 and 2 ensure that country $A$ cannot win competition for FDI by setting a lump-sum tax.

We solve our two-stage game by backward induction. At the second (and last) stage, the multinational firm invests in country $B$ if and only if

$$
\left(1-t_{B}\right) \Pi_{B}+S_{B}>\left(1-t_{A}\right) \Pi_{A}+S_{A}
$$

where the values of $t_{i}$ and $S_{i}$ depend on the first-stage policy competition scenario.

Under lump-sum subsidy competition (for given statutory corporate tax rates), the maximum amount (lump-sum subsidy) that country $i$ is willing to offer to the foreign investor, $S_{i}^{\max }$, consists in the country's tax revenue from inward FDI. Hence, it is represented by a full reimbursement of the taxes paid by the multinational firm on the profits it declares to country $i$ 's tax authorities. That is, in the absence of profit shifting, $S_{i}^{\max }=t_{i} \Pi_{i}, i=A, B$. The equilibrium subsidy results from an auction where the country representing the most attractive (subsidy inclusive) location receives the investment by the foreign firm. However, the winning country need not actually pay its maximum subsidy but just the one which is necessary to outbid the rival country, which 
is given by $S_{i}^{*} \equiv\left(1-t_{j}\right) \Pi_{j}+S_{j}^{\text {max }}-\left(1-t_{i}\right) \Pi_{i}, i, j=A, B, i \neq j .{ }^{13}$ Therefore, if both governments bid their maximum subsidy to attract FDI, country $B$ wins the auction and investment takes place there if and only if

$$
\left(1-t_{B}\right) \Pi_{B}+S_{B}^{\max }>\left(1-t_{A}\right) \Pi_{A}+S_{A}^{\max } \Longleftrightarrow \Pi_{B}>\Pi_{A}
$$

which always holds by Assumption 1. This implies that, in the absence of profit shifting, lump-sum subsidy competition cancels out country $B$ 's fiscal disadvantage relative to $A$, thereby inducing the foreign firm to set up its production plant there. In this case, the equilibrium subsidy is given by

$$
S_{B}^{*}=\Pi_{A}-\left(1-t_{B}\right) \Pi_{B}
$$

with $S_{B}^{*}>0$ by Assumption 3 .

Under targeted tax competition, governments choose the rate $\tau_{i}$ at which the multinational firm's declared profits are taxed. Country A's best offer to the foreign firm is represented by the possibility of not paying taxes at all there, i.e., by $\tau_{A}=0$. For country $B$ to attract FDI, its offer has to outbid country $A$ 's best offer. The problem of country $B$ 's government can then be written as follows:

$$
\begin{array}{cl}
\max _{\tau_{B}} & \tau_{B} \pi_{B} \\
\text { s.t. } & \left(1-\tau_{B}\right) \Pi_{B} \geq \Pi_{A}
\end{array}
$$

where $\pi_{B}=\Pi_{B}$ as, for the time being, we assume that the firm cannot misdeclare the profits actually realized at each location. If the constraint were not binding, there would be no real competition for FDI between the two countries. Then, as we are not interested in cases where policy competition resolves into a new tax instrument for country $B$, the solution comes from the constraint holding with equality, which gives

$$
\tau_{B}^{*}=1-\frac{\Pi_{A}}{\Pi_{B}} \in(0,1) .
$$

Therefore, country $B$ always wins the competition for FDI by fully extracting the foreign firm's location gain from investing there, $\Pi_{B}-\Pi_{A}>0$.

Once the equilibria under no policy, subsidy and tax competition have been characterized we can analyse whether competition to attract FDI is wasteful for the region as a whole. In the first instance, we argue that whenever policy competition does not change the investment decision of the foreign multinational, regional welfare is always lower than in the no policy competition scenario. In fact, we want to focus on situations where both countries could potentially receive FDI, hence they actually have to compete

\footnotetext{
${ }^{13}$ The same equilibrium outcome arises if we assume Bertrand price competition between countries. We provide a more general and formal definition of the equilibrium of the policy-competition-for-FDI games in the Appendix.
} 
against each other to affect the firm's choice. Under no policy competition, if the multinational chooses to invest in country $B$, regional welfare is given by $W_{B, N o}^{R}=t_{B} \Pi_{B}$. Under lump-sum subsidy competition, country $B$ always succeeds in attracting FDI but regional welfare decreases to $W_{B, S u b}^{R}=t_{B} \Pi_{B}-S_{B}^{*}=\Pi_{B}-\Pi_{A}<W_{B, N o}^{R}$ since $S_{B}^{*}>0$ by Assumption 3. Similarly, under targeted tax competition, regional welfare is equivalent to the lump-sum subsidy competition scenario, thus lower than without competition.

Absent policy competition and profit shifting, however, the firm might choose to invest in the fiscally-advantageous country $A$ in order to save on tax payments. If this were the case, both forms of policy competition may increase regional welfare by making the multinational invest in the location-advantageous country $B$. If the increase in overall surplus generated by the efficient location choice is larger that the loss of resources due to policy competition, there is room for increasing welfare for the region as a whole. The following proposition summarises the results of this section.

Proposition 1 Assume that there are no profit shifting opportunities for a multinational firm willing to invest in one of the countries competing to attract FDI. In the presence of different statutory corporate tax rates, lump-sum subsidy and targeted tax competition are equivalent and restore the efficiency of the firm's location choice. Furthermore, when the difference in statutory corporate tax rate within the region is sufficiently large, the region as a whole benefits from policy competition for FDI between countries.

Proof. See the Appendix.

The main message is that, in the absence of profit shifting, large differentials in statutory corporate tax rates between the two countries may drive the FDI decision of the multinational firm in a way which does not maximize welfare for the region as a whole. In this case, allowing countries to compete for FDI may increase regional welfare since policy competition makes the firm invest in the most profitable (before-taxes) location.

In the next Section, we investigate whether the potentially positive impact of policy competition for FDI and the equivalence between the different fiscal policies we analyze are robust to profit shifting by the multinational firm in response to tax rate differentials.

\section{Profit shifting}

We now investigate a set-up where the foreign multinational is able to shift, at some cost, taxable profits to low-tax jurisdictions in response to cross-country tax differentials. To this end, we solve by backward induction the three-stage game described at the beginning of Section 2 to find its Subgame perfect equilibrium. 


\subsection{Stage 3: profit declaration}

At the last stage of the game, the foreign multinational chooses the amount of profits to declare to the tax authorities of the countries where it operates, that is either $A$ or $B$, and $F$. When taking such a decision, the firm observes the statutory corporate tax rates in country $i(i=A, B)$ and country $F$, the fiscal incentives offered by countries $A$ and $B$ if policy competition occurs, and the level of before-tax profits it can realises in the chose location. The firm then chooses the amount of profits to declare to country $i$ 's tax authorities, $\pi_{i}$, in order to maximize its after-tax profits. This, in turn, determines the level of declared profits in country $F, \pi_{F}$.

The objective function of the MNE, as defined in (1), is the sum of the after-tax profits in country $F$ and in the chosen location. Optimizing with respect to $\pi_{i}$, we obtain

$$
\pi_{i}=\Pi_{i}-\frac{t_{i}-t_{F}}{\gamma} \quad \text { and } \quad \pi_{F}=\Pi_{F}+\frac{t_{i}-t_{F}}{\gamma}
$$

from which it follows that no profit misdeclaration takes place when countries $i$ and $F$ tax corporate profits at the same rate. However, for any $t_{i} \neq t_{F}$, the multinational always declares higher profits than those actually realized in the lower-tax country and lower profits in the higher-tax country. Note also that any kind of lump-sum subsidy set by countries $A$ and $B$ does not affect the multinational firm's profit declaration choice. Since we do not want the firm to declare negative profits in the high-tax country, which would otherwise subsidize it at the prevailing statutory corporate tax rate, we assume that profit shifting is costly enough, i.e.

$$
\gamma>\frac{\left|t_{i}-t_{F}\right|}{\min \left\{\Pi_{i}, \Pi_{F}\right\}}, \quad i=A, B .
$$

In what follows, we call (8) the non-negative-profit-declaration condition.

\subsection{Stage 2: FDI decision}

At the second stage, the foreign multinational chooses whether to establish its production plant in country $A$ or in country $B$, and, depending on its investment decision, realizes profits $\Pi_{A}$ or $\Pi_{B}$. At this stage of the game, the firm takes the fiscal policies of the two countries as given and invests in the country where it earns larger after-tax profits.

Using the firm's objective function (1), where we substitute for stage-3 optimal declared profits (7), and rearranging terms, the multinational's after-tax profits from investing in country $i$ and shifting profits out of (or into) country $F$ under the policy competition scenario $k \in\{N o, S u b, T a x\}$ can be rewritten as ${ }^{14}$

$$
\Pi^{i, k}=\left(1-t_{i}\right) \Pi_{i}+\left(1-t_{F}\right) \Pi_{F}+S_{i}+\frac{\left(t_{i}-t_{F}\right)^{2}}{2 \gamma}, \quad i=A, B
$$

\footnotetext{
${ }^{14}$ The terms No, Sub, and Tax stand for no policy, lump-sum subsidy and targeted tax competition, respectively.
} 
where the last term represents the net gain to shift taxable profits from the high-tax to the low-tax country in response to any tax differential between them.

\section{No policy competition}

If countries $A$ and $B$ do not compete to attract FDI $\left(S_{i}=0, i=A, B\right)$, the foreign multinational invests in country $B$ as long as the following condition holds:

$$
\left(1-t_{B}\right) \Pi_{B}+\underbrace{\frac{\left(t_{B}-t_{A}\right)\left(\bar{t}-t_{F}\right)}{\gamma}}_{\text {relative PS gain/loss }}>\left(1-t_{A}\right) \Pi_{A}
$$

where $\bar{t} \equiv \frac{t_{A}+t_{B}}{2}$ is the average statutory corporate tax rate in the region and $P S$ is an acronym for profit shifting.

A comparison of (10) with the corresponding condition in the absence of profit shifting, i.e., condition (3), suggests that, for a given $t_{B}>t_{A}$, profit shifting opportunities may turn the fiscally-disadvantageous country $B$ into a relatively more (less) attractive location for the foreign firm's investment when the average tax rate prevailing in the region is higher (lower) than the residence country's tax rate. In particular, when $\bar{t}>t_{F}$, the multinational finds relatively more interesting to invest in the higher-tax country as profit shifting (towards country F) partially offsets country $B$ 's fiscal disadvantage. Otherwise, when $\bar{t}<t_{F}$, profit shifting opportunities work in favor of the lower-tax country. Stated differently, if profit shifting goes out of (into) the region, the country setting the higher (the lower) corporate tax rate becomes, ceteris paribus, more attractive. In spite of that, in the presence of profit shifting, larger tax differentials always make the fiscally-advantageous country $A$ more profitable from the foreign firm's perspective as the gain from shifting profits out of the high-tax country cannot compensate for the cost of paying taxes there. Then, condition (10) is less likely to hold. ${ }^{15}$

\section{Lump-sum subsidy competition}

Under lump-sum subsidy competition (for given statutory corporate tax rates), countries $A$ and $B$ offer lump-sum subsidies that affect the relative profitability of the two alternative locations. In particular, when each country bids its maximum subsidy, $S_{i}^{\text {max }}$ $(i=A, B)$, the foreign multinational invests in country $B$ if and only if

$$
\left(1-t_{B}\right) \Pi_{B}+\frac{\left(t_{B}-t_{A}\right)\left(\bar{t}-t_{F}\right)}{\gamma}+S_{B}^{\max }>\left(1-t_{A}\right) \Pi_{A}+S_{A}^{\max }
$$

\section{Targeted tax competition}

\footnotetext{
${ }^{15}$ This can be easily seen by differentiating (10) with respect to $t_{A}$ or $t_{B}$ and recalling the non-negativeprofit-declaration condition (8).
} 
Under targeted tax competition, countries $A$ and $B$ compete over tax rates, $\tau_{i}$, and the foreign multinational invests in country $B$ as long as

$$
\left(1-\tau_{B}\right) \Pi_{B}+\frac{\left(\tau_{B}-\tau_{A}\right)\left(\bar{\tau}-t_{F}\right)}{\gamma}>\left(1-\tau_{A}\right) \Pi_{A}
$$

where $\bar{\tau} \equiv \frac{\tau_{A}+\tau_{B}}{2}$ is the average ad hoc corporate tax rate of the two countries. The tax rate $\tau_{i}$ results from the optimization problem of country $i$, which we analyze - together with lump-sum subsidy competition - in the next subsection.

\subsection{Stage 1: policy competition for FDI}

At the first stage, the governments of countries $A$ and $B$ simultaneously and irreversibly post bids to attract the foreign investor. The objective of each country's government is to maximize the national welfare gain from receiving FDI as given by (2).

\section{No policy competition}

Under no policy competition, the two countries do not offer any tax incentive to the foreign multinational. Hence, the firm takes its investment decision according to condition (10) and the equilibrium values of regional welfare and firm's after-tax profits are defined as follows. When FDI goes to country $A$ :

$$
\begin{aligned}
W_{A, N o}^{R} & =t_{A} \pi_{A}=t_{A} \Pi_{A}-\frac{t_{A}\left(t_{A}-t_{F}\right)}{\gamma} \\
\Pi^{A, N o} & =\left(1-t_{A}\right) \Pi_{A}+\left(1-t_{F}\right) \Pi_{F}+\frac{\left(t_{F}-t_{A}\right)^{2}}{2 \gamma},
\end{aligned}
$$

while when FDI goes to country $B$ :

$$
\begin{aligned}
W_{B, N o}^{R} & =t_{B} \pi_{B}=t_{B} \Pi_{B}-\frac{t_{B}\left(t_{B}-t_{F}\right)}{\gamma} \\
\Pi^{B, N o} & =\left(1-t_{B}\right) \Pi_{B}+\left(1-t_{F}\right) \Pi_{F}+\frac{\left(t_{F}-t_{B}\right)^{2}}{2 \gamma} .
\end{aligned}
$$

\section{Lump-sum subsidy competition}

Under lump-sum subsidy competition, the maximum subsidy country $i$ is willing and able to offer is represented by a full reimbursement of the taxes paid on the profits declared by the firm to country $i$ 's tax authorities, that is, $S_{i}^{\max }=t_{i} \pi_{i}(i=A, B)$. Since profit shifting allows the firm to misdeclare realized profits at each location in response to tax rate differentials, the maximum subsidies bid by countries $A$ and $B$ are given by

$$
S_{A}^{\max }=t_{A}\left(\Pi_{A}-\frac{t_{A}-t_{F}}{\gamma}\right) \quad \text { and } \quad S_{B}^{\max }=t_{B}\left(\Pi_{B}-\frac{t_{B}-t_{F}}{\gamma}\right)
$$

where we replace $\pi_{i}$ with stage-3 optimal declared profits as defined in (7). 
Substituting for the two countries' maximum subsidies (17) in equation (11) and rearranging terms, we can show that, with subsidy competition, FDI can go to country $A$, which is the inefficient location. In fact only when

$$
\Pi_{B}-\Pi_{A}>\frac{\left(t_{B}-t_{A}\right) \bar{t}}{\gamma}
$$

subsidy competition induces the multinational to invest in country $B$, which occurs when profit shifting motivations are less important for the firm than the location advantage of setting up a production plant there. In the presence of profit shifting, indeed, lump-sum subsidy competition cannot offset country $B$ 's fiscal disadvantage relative to $A$. The following Proposition summarises the result.

Proposition 2 If the multinational firm can use profit shifting opportunities to minimize its worldwide tax liabilities, (lump-sum) subsidy competition does not always induce the efficient allocation.

When condition (18) holds, country $B$ wins the competition for FDI. In equilibrium, however, it does not need to pay its maximum subsidy but just the one which is necessary to outbid its competitor. Hence, the equilibrium subsidy country $B$ pays to attract FDI in the presence of profit shifting opportunities for the firm amounts to

$$
\tilde{S}_{B}^{*}=S_{B}^{*}+\frac{2 t_{B} t_{F}-t_{B}^{2}-t_{A}^{2}}{2 \gamma}
$$

where $S_{B}^{*}$ is country $B$ 's equilibrium subsidy in the absence of profit shifting as defined in (5). Thus, depending on statutory corporate tax rates, $\tilde{S}_{B}^{*}$ can be either higher or lower than $S_{B}^{*}$. In particular, if the multinational is interested in shifting taxable profits into the region $\left(t_{F}>t_{A}, t_{B}\right)$ or simply to the lower-tax country $\left(t_{B}>t_{F}>t_{A}\right)$, the subsidy country $B$ has to pay to attract the foreign investor is higher than without profit shifting, i.e. $\tilde{S}_{B}^{*}>S_{B}^{*}$. Otherwise, for $t_{A}, t_{B}>t_{F}$, the multinational finds it relatively more profitable to invest in the higher-tax country as it can now shift taxable profits out of the region, which leads to $\tilde{S}_{B}^{*}<S_{B}^{*}$.

The discussion above allows us to conclude that, in the presence of profit shifting, both countries can win subsidy competition for FDI. If country $B$ attracts the foreign investor, regional welfare is equal to

$$
W_{B, S u b}^{R}=t_{B} \pi_{B}-\tilde{S}_{B}^{*}=\Pi_{B}-\Pi_{A}-\frac{\left(t_{B}-t_{A}\right) \bar{t}}{\gamma}
$$

and, substituting for $\tilde{S}_{B}^{*}$ into equation (9), the multinational's after-tax profits from investing in country $B$ and shifting profits out of (or into) country $F$ are given by

$$
\Pi^{B, S u b}=\Pi_{A}+\left(1-t_{F}\right) \Pi_{F}+\frac{t_{F}^{2}-t_{A}^{2}}{2 \gamma}
$$


On the other hand, if it is country $A$ that receives FDI, regional welfare is given by

$$
W_{A, S u b}^{R}=t_{A} \pi_{A}-\tilde{S}_{A}^{*}=\frac{\left(t_{B}-t_{A}\right) \bar{t}}{\gamma}-\left(\Pi_{B}-\Pi_{A}\right)=-W_{B, S u b}^{R}
$$

where $\tilde{S}_{A}^{*}=\Pi_{B}-\left(1-t_{A}\right) \Pi_{A}+\frac{2 t_{A} t_{F}-t_{B}^{2}-t_{A}^{2}}{2 \gamma}$ is derived in the same way as $\tilde{S}_{B}^{*}$. It is then immediate to compute the multinational's after-tax profits from investing in country $A$ and shifting profits out of (or into) country $F$ by replacing $\tilde{S}_{A}^{*}$ into equation (9):

$$
\Pi^{A, S u b}=\Pi_{B}+\left(1-t_{F}\right) \Pi_{F}+\frac{t_{F}^{2}-t_{B}^{2}}{2 \gamma}
$$

\section{Targeted tax competition}

Under targeted tax competition, the two governments compete over the ad hoc tax rate $\tau_{i}$ at which the multinational firm's declared profits are taxed. The problem of country $B$ 's government is given by

$$
\begin{array}{ll}
\max _{\tau_{B}} & \tau_{B} \pi_{B} \\
\text { s.t. } & \left(1-\tau_{B}\right) \Pi_{B}+\frac{\left(\tau_{B}-\tau_{A}\right)\left(\bar{\tau}-t_{F}\right)}{\gamma} \geq\left(1-\tau_{A}\right) \Pi_{A}
\end{array}
$$

with $\pi_{B}=\Pi_{B}-\frac{\tau_{B}-t_{F}}{\gamma}$ from (7). The following Proposition defines the solution to the optimization problem of country $B$.

Proposition 3 When the multinational firm can use profit shifting opportunities to minimize its worldwide tax liabilities, targeted tax competition always induces the effcient location choice. Furthermore country B wins the tax competition game by bidding an ad hoc tax rate

$$
\hat{\tau}_{B}=\gamma \Pi_{B}+t_{F}-\sqrt{\left(\gamma \Pi_{B}+t_{F}\right)^{2}-2 \gamma\left(\Pi_{B}-\Pi_{A}\right)}
$$

which is always increasing in $\Pi_{B}$.

Proof. See Appendix.

The intuition for the first part of the Proposition 3 is simple. When the two countries' governments are allowed to choose an ad hoc corporate tax rate for the foreign investor's profits, the distortions introduced by statutory tax rate differentials and by the profit shifting behavior of the multinational firm can be eliminated. Then, the country where the firm may enjoy the largest (before-tax) profits always wins the competition for FDI. ${ }^{16}$

\footnotetext{
${ }^{16}$ This reminds us the well-known result in the IO literature on vertical product differentiation according to which if a high and a low quality good are offered at the same price, then all consumers will buy the high quality good (see, e.g., Pepall et al., 2008). Here, absent tax distortions, country $B$ will benefit from a higher intrinsic quality relative to country $A$ because of its location advantage.
} 
The second result suggests that the larger the before-tax profitability from investing in $B$ (due to, e.g., a larger market size relative to $A$ ), the lower the incentive to tax discriminate in favor of MNE, i.e., the higher the tax rate that country $B$ bids to attract the foreign investor.

Hence, in equilibrium, country $B$ always wins the competition for FDI by setting a positive tax rate on the foreign firm's declared profits. Regional welfare is then given by

$$
W_{B, T a x}^{R}=W_{B}^{B}=\Pi_{B}-\Pi_{A}-\frac{\hat{\tau}_{B}^{2}}{2 \gamma}
$$

and it represents the marginal contribution of country $B$ to aggregate welfare (or total surplus), defined as the unweighted sum of regional welfare and the firm's after-tax profits. ${ }^{17}$ In fact, such a contribution corresponds to the location advantage of $B$ over $A, \Pi_{B}-\Pi_{A}$, minus the loss in terms of overall potential gains from profit shifting, that is, $\left[t_{F} \frac{t_{F}-\hat{\tau}_{B}}{\gamma}-\frac{\left(t_{F}-\hat{\tau}_{B}\right)^{2}}{2 \gamma}\right]-\left[t_{F} \frac{t_{F}}{\gamma}-\frac{t_{F}^{2}}{2 \gamma}\right]=-\frac{\hat{\tau}_{B}^{2}}{2 \gamma}$.

The equilibrium profit for the multinational firm is:

$$
\Pi^{B, T a x}=\left(1-\hat{\tau}_{B}\right) \Pi_{B}+\left(1-t_{F}\right) \Pi_{F}+\frac{\left(\hat{\tau}_{B}-t_{F}\right)^{2}}{2 \gamma}
$$

\subsection{Regional welfare implications}

In this Section, we evaluate the welfare impact of profit shifting by the foreign multinational investing in the region. In particular, we investigate whether the introduction of policy competition may enhance regional welfare by changing the foreign firm's investment decision. Moreover, we show under which conditions targeted tax competition (hence, tax discrimination) has to be preferred to lump-sum subsidy competition.

It is easy to check that, in the presence of profit shifting, subsidy and tax competition are no longer equivalent since the former may not be able to induce the firm to make the efficient FDI choice. When countries compete over tax rates, country $A$ offers a tax holiday to the foreign firm whereas country $B$ proposes an ad hoc tax rate that is positive due to its location advantage. The foreign firm takes into account the possibility of shifting taxable profits to the tax-preferred jurisdiction when deciding where to set up its production plant. Hence, it will optimally shift into the lower-tax country as much of its profits as it can. In equilibrium, country $B$ will be able to set a tax rate which always induces the foreign firm to invest there. However, the firm cannot fully enjoy the location specific rents from locating in $B$ because of the loss in terms of profit shifting. On the other hand, lump-sum subsidy competition does not affect profit declaration and profit shifting motivations play a decisive role for the FDI choice.

\footnotetext{
${ }^{17}$ Our results can be easily interpreted in the light of the common agency literature since our model considers two principals (the two governments) that submit offers to a common agent (the foreign investor). In particular, Chiesa and Denicolò (2009) show that in a common agency game with two principals and complete information, each principal's payoff corresponds exactly to its marginal contribution to social surplus even when we relax the assumption of truthful strategies.
} 
To investigate the effects on regional welfare of policy competition for FDI in the presence of profit shifting, we assume that either form of competition always decreases regional welfare when it does not change the multinational firm's investment decision:

Assumption $4 W_{i, k}^{R}<W_{i, N o}^{R}, k \in\{S u b, T a x\}$

This allows us to exclude from the analysis the cases where policy competition resolves into a new tax instrument for the host country and to focus on situations where competition for FDI actually takes place as both countries represent profitable locations (either before or after taxes) for the firm. Assumption 4 thus implies that under lumpsum subsidy competition, both countries have to pay positive equilibrium subsidies to attract FDI; or under tax competition, the cost for country $B$ of lowering the corporate tax rate on the foreign firm's profits cannot compensate for the gain from partial rent extraction.

For country $B$, Assumption 4 implies that $W_{B, N o}^{R}>W_{B, S u b}^{R}$ and $W_{B, N o}^{R}>W_{B, T a x}^{R}$. For country $A$, instead, we have that $W_{A, N o}^{R}>W_{A, S u b}^{R}$ as tax competition cannot induce the firm to invest there. Note also that, differentiating (14) with respect to $t_{A}$, we obtain that $\frac{\partial W_{A, N o}^{R}}{\partial t_{A}}>0$ if and only if $\gamma>\frac{2 t_{A}-t_{F}}{\Pi_{A}} .{ }^{18}$ Since $t_{B}>t_{A}$ by Assumption 2, a lower $t_{A}$, for a given $t_{B}$, increases the tax difference between them and, if $\gamma$ is high enough, i.e, if profit shifting is sufficiently costly, it decreases regional welfare from FDI to $A$ under no policy competition.

We want to show that policy competition may increase regional welfare by changing the firm's FDI decision. In particular, we compare $W_{B, S u b}^{R}$ with $W_{A, N o}^{R}$. The latter is the best situation for the region as a whole when FDI goes to $A$, and, for this to happen, the multinational has to find it profitable to invest in country $A$ in the absence of policy competition, i.e., $\Pi^{A, N o}>\Pi^{B, N o}$ must hold. It is also easy to check that the welfare of country $B$ - hence, of the region - corresponds to the marginal contribution of country $B$ to aggregate welfare, and it can thus be defined as the difference between aggregate welfare when the firm invests in $B$ and when it invests in $A$, i.e., $W_{B, S u b}^{R}=$ $W_{B, N o}^{R}+\Pi^{B, N o}-\left(W_{A, N o}^{R}+\Pi^{A, N o}\right)$. Therefore, provided that $\Pi^{A, N o}>\Pi^{B, N o}$, regional welfare increases as a result of subsidy competition as long as

$$
W_{B, N o}^{R}>\Pi^{A, N o}-\Pi^{B, N o}+2 W_{A, N o}^{R}
$$

which is more likely to be true when the relative after-tax profitability from investing in $A$ over $B$ essentially depends on a low statutory corporate tax rate $t_{A}$ or on an important difference between $t_{A}$ and $t_{B}$. Indeed, a lower $t_{A}$ increases $\Pi^{A, N o}$ but, if profit shifting is costly enough, it simultaneously reduces tax revenues (hence, regional welfare from FDI to $A$ ). This allows us to claim

\footnotetext{
${ }^{18}$ If $t_{F}<t_{A}$, the firm shifts taxable profits to country $F$ and $W_{A, N o}^{R}$ increases with $t_{A}$ if and only if $\gamma$ is high enough, meaning that profit shifting is limited by its cost. If $t_{F}>2 t_{A}, W_{A, N o}^{R}$ always increases with $t_{A}$ since $t_{F}$ is so high that $\gamma$ becomes negligible. Finally, if $t_{F} \in\left(t_{A}, 2 t_{A}\right)$, the firm shifts taxable profits to country $A$, which can increase its tax revenue by increasing $t_{A}$ as long as $\gamma$ is high enough.
} 
Proposition 4 In the presence of profit shifting, lump-sum subsidy competition for FDI may be beneficial to the region if the difference in statutory corporate tax rates within the region is large enough.

In fact, for a sufficiently large statutory tax rate difference, we know that the multinational firm prefers to invest in the fiscally-advantageous country $A$ absent policy competition. But as we let this difference increase further - by decreasing $t_{A}$, for a given $t_{B}$ - regional welfare from FDI to $A$ may decrease. Hence, lump-sum subsidy competition may be regional-welfare improving since it induces the firm to invest in the locationadvantageous country $B$. This is true provided that profit shifting is so costly that a reduction in $t_{A}$ does not allow country $A$ to increase the revenue it can collect by taxing the multinational firm's profits.

Lastly, we want to demonstrate that, in the presence of profit shifting, targeted tax competition might be more desirable than subsidy competition as a policy instrument to attract FDI. To this end, we need to compare $W_{B, T a x}^{R}$ and $W_{B, S u b}^{R}$, notably the impact of profit shifting under the two policies, which would otherwise be equivalent. It is then straightforward to show that

$$
W_{B, \text { Tax }}^{R}>W_{B, S u b}^{R} \quad \Longleftrightarrow \quad \hat{\tau}_{B} \in\left(0, \sqrt{\left(t_{A}-t_{B}\right)\left(t_{A}+t_{B}\right)}\right)
$$

since $\hat{\tau}_{B}$ cannot be negative. Such a condition is more likely to hold the higher the statutory corporate tax rate difference or the sum (i.e., the average) of tax rates or both are. We can thus state

Proposition 5 In the presence of profit shifting, targeted tax competition is more likely to yield higher regional welfare than lump-sum subsidy competition for FDI when the difference in statutory corporate tax rates within the region and/or the average statutory corporate tax rate prevailing in the region are large enough.

To understand why this is so, we just need to look at regional welfare from FDI to country $B$ under subsidy competition, $W_{B, S u b}^{R}=\Pi_{B}-\Pi_{A}-\frac{\left(t_{B}-t_{A}\right) \bar{t}}{\gamma}$, since regional welfare under tax competition, $W_{B, T a x}^{R}$, does not depend on the statutory corporate tax rates $t_{A}$ and $t_{B}$. We know that $W_{B, S u b}^{R}$ represents country $B$ 's marginal contribution to aggregate welfare, where the latter is defined as the sum of regional welfare and the firm's after-tax profits, thereby excluding country $F$. For a given average statutory tax rate in the region $\bar{t}$, a larger difference $\left(t_{B}-t_{A}\right)$ decreases country $B$ 's marginal contribution since the amount of taxable profits the multinational firm shifts into the region shrinks (or, similarly, profit shifting to the residence country $F$ gets larger). On the other hand, for a given statutory tax rate difference within the region $\left(t_{B}-t_{A}\right)$, a higher average tax rate $\bar{t}$ lowers country $B$ 's marginal contribution because a symmetric increase in statutory tax rates - that keeps the difference between them constant - has a negative effect on aggregate welfare and such an effect is stronger for the country with the higher statutory tax rate. 


\section{Concluding remarks}

The phenomenon of competition for FDI is pervasive and mostly takes place between countries belonging to the same geographic, political or economic area. The incentives offered to foreign investors often consist in tax holidays or other kinds of specific tax concessions. Moreover, the empirical evidence seems to suggest that multinational firms might consider profit shifting opportunities when deciding the location of their foreign subsidiaries. In order to counter what policymakers label harmful tax competition between governments, the non-discrimination principle has been strongly advocated by both the European Union and the OECD. This should prevent countries from offering targeted fiscal incentives to attract foreign investors. But there is empirical evidence to the contrary.

The objective of this paper has been to investigate the impact on regional welfare of policy competition for FDI when a foreign multinational can strategically react to differences in statutory corporate tax rates and shift taxable profits to lower-tax jurisdictions. In particular, we have tried to understand whether it can be welfare-improving for the region as a whole that countries compete against each other by offering further tax incentives when their national corporate tax systems already give the multinational some opportunities to minimize its worldwide tax liabilities. To this end, we have set up a model of policy competition for FDI between two countries belonging to the same region, and we have assumed that one country has a location advantage but a fiscal disadvantage relative to the other one.

If we rule out profit shifting opportunities, any form of policy competition eliminates tax distortions and induces the foreign multinational to invest in the locationadvantageous country. Moreover, when the statutory tax rate difference is large enough, policy competition increases regional welfare by changing the investment decision of the firm. On the other hand, when we take profit shifting opportunities into account, subsidy competition can no longer offset tax distortions. Then, profit shifting motivations may induce the firm to invest in the fiscally-advantageous country. By contrast, targeted tax competition cancels out the distortions arising from statutory tax rate differentials and induces the foreign firm to choose the most efficient location for its investment. In spite of that, lump-sum subsidy competition may still be regional-welfare-improving when the statutory tax rate difference is large enough.

Our main contribution has been to prove that, in the presence of profit shifting, targeted tax competition might be preferable - in terms of regional welfare - to lumpsum subsidy competition as a policy instrument to attract FDI. This is more likely to be true when the statutory tax rate difference within the region and/or the average tax rate prevailing in the region are high. Such a result has important policy implications for, e.g., the European Union, an area characterized by both high tax levels and high tax differentials. Indeed, it challenges the propriety of the non-discrimination principle. This principle, by restricting the policy instrument set at the governments' disposal to 
attract FDI, induces countries to compete in a way that might end up lowering regional welfare. In this context, tax discrimination, i.e., a policy which is more able to adjust to the profit shifting activities of multinational firms, might lead to larger benefits than lump-sum subsidy competition.

We conclude with two remarks on our modeling choices. First, we restrict attention to tax instruments to attract FDI. This is because we want to focus on policies that affect profit declaration by the multinational firm, hence its profit shifting ability in response to the fiscal incentives offered by competing countries. To this end, we do not let governments choose, e.g., the level of public infrastructure (roads, bridges, rail connections, airports, etc.) supplied to the firm. This, however, might be somehow captured by the exogenous difference in before-tax profitability between the two locations as long as we consider infrastructure as a local public good, whose benefits can be enjoyed by the firm only by locating in the country where the investment has been made. ${ }^{19}$

Second, our set-up is characterized by complete information, i.e., the economic agents (the governments and the multinational firm) know everything they need to know to take the decisions which maximize their payoffs. But there are several ways to introduce asymmetric information in our framework. ${ }^{20}$ For instance, by assuming that the foreign multinational possesses private information on its outside option from not investing in the region. That is, the two governments just have some common expectations about the profitability of an alternative location outside the region for the foreign multinational. If governments are not able to elicit information from the firm, however, the uncertainty about the value of such an outside option simply resolves into a further constraint that they may have to take into account when competing for FDI. A more interesting situation, instead, occurs when the fiscal policy of the host country indirectly affects the value of the outside option. If, for example, the outside option of the foreign multinational is given by the possibility of not investing abroad, operating just in its residence country and paying taxes at some unknown rate there, profit shifting creates a link between the fiscal policies of the residence and of the host country. Hence, the host country might be able to design a fiscal policy which induce truthful revelation by the foreign firm. But this goes beyond the scope of our model and represents a task for future research.

\footnotetext{
${ }^{19}$ In general, when countries face a set of firms heterogeneous with respect to their infrastructure needs, they have an incentive to differentiate to the maximum extent as this allows them to reduce the dissipation of welfare resulting from subsequent tax competition. In such a sense, infrastructure competition can relax tax competition in the same way as product differentiation can relax price competition between firms. Hindiks et al. (2008), however, show that the opposite result may hold under revenue sharing when countries are heterogeneous ex ante in their capacity to attract capital. In particular, countries strategically choose to under-invest in public infrastructure as they anticipate that public investments, by enhancing the productivity of capital, will exacerbate subsequent capital tax competition. See Dembour (2008) for a recent survey of the literature about tax and infrastructure competition.

${ }^{20}$ Bond and Samuelson (1986), e.g., analyze a situation where the firm is uncertain as to the productivity of the country where it will potentially invest, and show that tax holidays are an optimal means by which high-productivity countries can reveal their type.
} 


\section{Appendix}

\section{No profit shifting}

\section{Policy-competition-for-FDI equilibrium}

Under lump-sum subsidy competition, if condition (4) holds, country $A$ can never succeed in attracting FDI even by bidding its maximum lump-sum subsidy $S_{A}^{\max }$. On the other hand, if condition (4) does not hold, it is country $B$ that can never win the competition for FDI. Hence, the subsidy-competition-for-FDI game between countries $A$ and $B$ is a Bertrand-competition-like game in prices with multiple equilibria. In particular, the equilibrium can be defined as follows:

$$
\begin{aligned}
& S_{i}^{*}=\epsilon, \quad \text { with } \epsilon \in\left(0, S_{i}^{\max }\right) \\
& S_{j}^{*}: \Pi^{j}\left(S_{j}^{*}\right)=\Pi^{i}\left(S_{i}^{\text {max }}\right), \text { for } i, j=A, B, i \neq j
\end{aligned}
$$

The proof is a straightforward application of the Bertrand-competition solution. Indeed, depending on condition (4), one of the two countries, say country $i$, can never attract the foreign investor. For country $i$, any bid $\epsilon \in\left(0, S_{i}^{\max }\right)$ is a best reply to country $j$ 's equilibrium strategy since its own payoff is always equal to zero. For country $j$, any other strategy $S_{j}^{\prime}<S_{j}^{*}$ is not an equilibrium strategy since country $i$ will have the opportunity of attracting FDI by setting $S_{i}^{\max }$, which would imply $\Pi^{i}\left(S_{i}^{\max }\right)>\Pi^{j}\left(S_{j}^{\prime}\right)$. By contrast, any other strategy $S_{j}^{\prime}>S_{j}^{*}$ is not a best reply to $S_{i}^{*}$ because it leaves to the foreign firm an extra-benefit that country $j$ could extract.

Under targeted tax competition, the problem of country $i$ 's government can be generally formulated in the following way:

$$
\begin{aligned}
\max _{t_{i}\left(\pi_{i}\right)} & t_{i}\left(\pi_{i}\right) \\
\text { s.t. } & \Pi_{i}-t_{i}\left(\pi_{i}\right) \geq \Pi_{j}-t_{j}\left(\pi_{j}\right), i, j=A, B, i \neq j
\end{aligned}
$$

where the fiscal policy implemented by country $i, t_{i}\left(\pi_{i}\right)$, is a function of the profits the multinational firm declares to country $i$ 's tax authorities.

The policy-competition-for-FDI game between countries $A$ and $B$ is a Bertrandcompetition-like game in prices with multiple equilibria. In particular, the equilibrium can be defined as follows

$$
\begin{aligned}
& t_{A}^{*}\left(\pi_{A}\right)=\epsilon, \text { with } \epsilon \in(0, \infty) \\
& t_{B}^{*}\left(\pi_{B}\right)=\Pi_{B}-\Pi_{A}
\end{aligned}
$$

The proof is a straightforward application of the Bertrand-competition solution. Indeed, for country $A$, any $\epsilon \in(0, \infty)$ is a best reply to country $B$ 's equilibrium strategy since $A$ 's payoff is always nil, i.e., it can never attract the foreign investor. For country $B$, any other strategy $t_{B}^{\prime}(\cdot)$ such that $t_{B}^{\prime}(\cdot)>\Pi_{B}-\Pi_{A}>0$ is not an equilibrium strategy since 
country $A$ will have the opportunity of attracting FDI by setting $t_{A}^{*}(\cdot)=\epsilon<t_{B}^{\prime}(\cdot)$. By contrast, any other strategy $t_{B}^{\prime}(\cdot)<\Pi_{B}-\Pi_{A}$ is not a best reply to $t_{A}^{*}(\cdot)$ because it leaves money on the table, i.e., to the foreign multinational firm.

\section{Proof of Proposition 1}

When $\left(1-t_{A}\right) \Pi_{A}>\left(1-t_{B}\right) \Pi_{B}$, the foreign multinational invests in country $A$ in the absence of policy competition and regional welfare is given by $W_{A}^{R}=t_{A} \Pi_{A}$. Competition between countries changes the FDI decision of the foreign multinational and regional welfare amounts to $W_{B}^{R}=\Pi_{B}-\Pi_{A}$. We want to show that $\Pi_{B}-\Pi_{A}>t_{A} \Pi_{A}$ may hold, in which case policy competition increases regional welfare. For this to be possible, two conditions have to be satisfied:

(i) the foreign investor chooses to invest in country $A$ in the absence of policy competition if and only if

$$
\Pi_{B}<\frac{1-t_{A}}{1-t_{B}} \Pi_{A}
$$

that is if the gain in before-tax profits from investing in $B$ cannot compensate for the fiscal disadvantage of operating in the high-tax country;

(ii) regional welfare increases if and only if

$$
\Pi_{B}>\left(1+t_{A}\right) \Pi_{A}
$$

Therefore, policy competition increases regional welfare by inducing the firm to invest in the location-advantageous country if and only if the last two conditions simultaneously hold, that is if and only if

$$
\frac{1-t_{A}}{1-t_{B}}>1+t_{A} \quad \Longleftrightarrow \quad t_{B}>\hat{t}_{B}\left(t_{A}\right) \equiv \frac{2 t_{A}}{1+t_{A}} \geq t_{A}
$$

For $t_{B} \in\left[t_{A}, \hat{t}_{B}\right)$, policy competition decreases regional welfare, whereas the opposite holds true for $t_{B} \in\left(\hat{t}_{B}, 1\right)$.

\section{Profit shifting}

\section{Lump-sum subsidy competition}

If country $B$ 's location advantage is more important for the foreign firm than profit shifting opportunities, i.e., condition (18) holds, country $A$ can never succeed in attracting FDI even by bidding its maximum lump-sum subsidy $S_{A}^{\max }$. On the other hand, if condition (18) does not hold, it is country $B$ that can never win the competition for FDI. Hence, similarly to the no-profit-shifting case, the equilibrium of the subsidycompetition-for-FDI game between countries $A$ and $B$ can be defined as follows

$$
\begin{aligned}
& S_{i}^{*}=\epsilon, \quad \text { with } \epsilon \in\left(0, S_{i}^{\max }\right) \\
& \tilde{S}_{j}^{*}: \Pi^{j}\left(\tilde{S}_{j}^{*}\right)=\Pi^{i}\left(S_{i}^{\text {max }}\right), \text { for } i, j=A, B, i \neq j
\end{aligned}
$$


The proof is once again a straightforward application of the Bertrand-competition solution. Indeed, depending on condition (18), one of the two countries, say country $i$, can never attract the foreign investor. For country $i$, any bid $\epsilon \in\left(0, S_{i}^{\max }\right)$ is a best reply to country $j$ 's equilibrium strategy since $i$ 's payoff is always equal to zero. For country $j$, any other strategy $S_{j}^{\prime}<\tilde{S}_{j}^{*}$ is not an equilibrium strategy since country $i$ will have the opportunity of attracting FDI by setting $S_{i}^{\max }$, which would imply $\Pi^{i}\left(S_{i}^{\max }\right)>\Pi^{j}\left(S_{j}^{\prime}\right)$. By contrast, any other strategy $S_{j}^{\prime}>\tilde{S}_{j}^{*}$ is not a best reply to $S_{i}^{*}$ because it leaves to the foreign firm an extra-benefit that country $j$ could extract.

\section{Targeted tax competition}

\section{Proof of Proposition 3}

Under tax competition, governments compete over the rate $\tau_{i}$ at which the multinational firm's declared profits are taxed. The problem of country $B$ 's government is given by

$$
\begin{array}{ll}
\max _{\tau_{B}} & \tau_{B} \pi_{B} \\
\text { s.t. } & \left(1-\tau_{B}\right) \Pi_{B}+\frac{\left(\tau_{B}-\tau_{A}\right)\left(\bar{\tau}-t_{F}\right)}{\gamma} \geq\left(1-\tau_{A}\right) \Pi_{A}
\end{array}
$$

where $\pi_{B}=\Pi_{B}-\frac{\tau_{B}-t_{F}}{\gamma}$ from (7). Since we are dealing with a single-variable maximization problem with one constraint, the solution is either an unconstrained maximum resulting from the maximization of the objective function without the constraint - or it comes from the constraint itself, which is binding. But if the constraint is not binding, there is no real competition for FDI between countries and the latter resolves into a new tax instrument for country $B$. Hence, we just consider the binding situation and we define

$$
f\left(\tau_{A}, \tau_{B}\right) \equiv\left(1-\tau_{B}\right) \Pi_{B}+\frac{\left(\tau_{B}-\tau_{A}\right)\left(\bar{\tau}-t_{F}\right)}{\gamma}-\left(1-\tau_{A}\right) \Pi_{A}=0
$$

so that the solution to country $B$ 's problem is given by

$$
\tau_{B}^{*}\left(\tau_{A}\right)=\gamma \Pi_{B}+t_{F} \pm \sqrt{\left(\gamma \Pi_{B}+t_{F}\right)^{2}+\tau_{A}\left(\tau_{A}-2 t_{F}\right)-2 \gamma\left[\Pi_{B}-\left(1-\tau_{A}\right) \Pi_{A}\right]}
$$

which, given country $A$ 's best offer to the foreign firm, i.e., $\tau_{A}=0$, reduces to

$$
\hat{\tau}_{B} \equiv \tau_{B}^{*}(0)=\gamma \Pi_{B}+t_{F} \pm \sqrt{\left(\gamma \Pi_{B}+t_{F}\right)^{2}-2 \gamma\left(\Pi_{B}-\Pi_{A}\right)}
$$

Note that $f(\cdot, \cdot)$ is a convex function of $\tau_{B}$ which is increasing for $\tau_{B}>\gamma \Pi_{B}+t_{F}$. If the two roots that we have just defined do not exist, this means that $f(\cdot, \cdot)>0$, i.e., the after-tax profits from investing in $B$ always exceed those from investing in $A$, hence country $B$ always attracts FDI for any $\tau_{B}$ it sets. If the two roots exist, instead, they will both be positive, but the only acceptable solution is the smaller one as the larger one 
violates the non-negative-profit-declaration condition, which requires $\tau_{B}<\gamma \Pi_{B}+t_{F} .{ }^{21}$ Therefore, country $B$ always attracts FDI by setting

$$
\tau_{B}^{*}(0) \equiv \hat{\tau}_{B}=\gamma \Pi_{B}+t_{F}-\sqrt{\left(\gamma \Pi_{B}+t_{F}\right)^{2}-2 \gamma\left(\Pi_{B}-\Pi_{A}\right)}
$$

and regional welfare is given by $W_{B, T a x}^{R}=W_{B}^{B}=\hat{\tau}_{B}\left(\Pi_{B}-\frac{\hat{\tau}_{B}-t_{F}}{\gamma}\right)=\Pi_{B}-\Pi_{A}-\frac{\hat{\tau}_{B}^{2}}{2 \gamma}$ where the last equality is obtained by using $f\left(0, \tau_{B}\right)=0$.

The equilibrium of the tax-competition game between countries $A$ and $B$ can be defined as follows:

$$
\begin{aligned}
& \tau_{A}^{*}=\epsilon, \quad \text { with } \epsilon \in(0, \infty) \\
& \hat{\tau}_{B}: \Pi^{B}\left(\hat{\tau}_{B}\right)=\Pi^{A}(0)
\end{aligned}
$$

Indeed, it is always possible for country $B$ to set a tax rate such that country $A$ can never attract the foreign investor. Any $\tau_{B}>\hat{\tau}_{B}$ is not an equilibrium strategy for country $B$ as it gives country $A$ the opportunity of attracting FDI with its best offer, i.e., $\tau_{A}=0$. By contrast, any $\tau_{B}<\hat{\tau}_{B}$ would leave money to the firm. For country $A$, then, any $\tau_{A} \in(0, \infty)$ is a best reply to $\hat{\tau}_{B}$ since $A$ always earns a zero payoff.

\section{References}

[1] Amerighi, O. 2008. "Transfer Pricing and Enforcement Policy in Oligopolistic Markets", in S. Brakman and H. Garretsen, eds., Foreign Direct Investment and the Multinational Enterprise. Cambridge, MA: MIT Press, pp.117-154.

[2] Bartelsman, E.J., and R.M.W.J. Beetsma. 2003. "Why Pay More? Corporate Tax Avoidance through Transfer Pricing in OECD Countries." Journal of Public Economics 87 (9-10): 2225-2252.

[3] Bartik, T.J. 1985. "Business Location Decisions in the United States: Estimates of the Effects of Unionization Taxes, and Other Characteristics of States." Journal of Business \& Economic Statistics 3: 1422.

[4] Bernheim, B.D., and M.D. Whinston. 1998. "Exclusive Dealing." Journal of Political Economy 106 (1): 64-103.

[5] Bjorvatn, K., and C. Eckel. 2006. "Policy Competition for Foreign Direct Investment between Asymmetric Countries." European Economic Review 50: 1891-1907.

[6] Bond, E.W., and L. Samuelson. 1986. "Tax Holidays as Signals." American Economic Review 76(4): 820-826.

\footnotetext{
${ }^{21}$ Notice that $\hat{\tau}_{B}<1$ when $\gamma>\frac{1-2 t_{F}}{2 \Pi_{A}}$, which we cannot say whether it is more or less stringent than the non-negative-profit-declaration condition (8). In any case, we assume that the most stringent of the two holds.
} 
[7] Bucovetsky, S., and A. Haufler. 2008. "Tax competition when firms choose their organizational form: Should tax loopholes for multinationals be closed?", Journal of International Economics 74: 188-201.

[8] Buettner, T., and M. Ruf. 2007. "Tax Incentives and the Location of FDI: Evidence from a Panel of German Multinationals." International Tax and Public Finance 14: 151-164.

[9] Charlton, A. 2003. "Incentive Bidding for Mobile Investment: Economic Consequences and Potential Responses." Working Paper No. 203, OECD Development Centre.

[10] Chiesa, G., and V. Denicolò. 2009. "Trading with a Common Agent under Complete Information: A Characterization of Nash Equilibria." Journal of Economic Theory 144(1): 296-311.

[11] Dembour, C. 2008. "Competition for Business Location: A Survey." Journal of Industry, Competition nd Trade 8: 89-111.

[12] De Mooij, R., and S. Ederveen. 2003. "Taxation and Foreign Direct Investment: A Synthesis of Empirical Research." International Tax and Public Finance 10: 673693.

[13] Devereux, M.P., and R. Griffith. 1998. "Taxes and the Location of Production: Evidence from a Panel of US Multinationals." Journal of Public Economics 68: 335-367.

[14] Devereux, M.P., and S. Loretz. 2012. "What do we know about corporate tax competition?" Working Paper 12/29, Oxford University Centre for Business Taxation, Said Business School, Oxford.

[15] European Communities. 31-3-1992. Conclusions and Recommendations of the Committee of Independent Experts on Company Taxation (Ruding Report). Brussels.

[16] European Communities. 1998. Conclusions of the ECOFIN Council Meeting on 1 December 1997 Concerning Taxation Policy (including Code of Conduct for Business Taxation). Official Journal of the European Communities 98/C 2/01. Brussels.

[17] Ferrett, B., and I. Wooton. 2010a. Competing for a Duopoly : International Trade and Tax Competition. Canadian Journal of Economics 43: 776-794.

[18] Ferrett, B., and I. Wooton. 2010b. Tax Competition and the International Distribution of Firm Ownership: An Invariance Result. International Tax and Public Finance 17: 518-531.

[19] Fumagalli, C. 2003. "On the Welfare Effects of Competition for Foreign Direct Investment." European Economic Review 47: 963-983. 
[20] Gresik, T. A. 2001. "The Taxing Task of Taxing Transnationals." Journal of Economic Literature, vol. XXXIX: 800-838.

[21] Haufler, A., and I. Wooton. 1999. "Country Size and Tax Competition for Foreign Direct Investment." Journal of Public Economics 71: 121-139.

[22] Haufler, A., and I. Wooton. 2006. Regional Tax Coordination and Foreign Direct Investment. European Economic Review 50: 285-305.

[23] Heckemeyer, J.H., and M. Overesch. 2013. Multinationals Profit Response to Tax Differentials: Effect Size and Shifting Channels. ZEW Discussion Paper No. 13-045.

[24] Hindriks, J., S. Peralta, and S. Weber. 2008. "Competing in Taxes and Investment under Fiscal Equalization." Journal of Public Economics 92(12): 2392-2402.

[25] Hines, J.R., and E.M. Rice. 1994. "Fiscal Paradise: Foreign Tax Havens and American Business." Quarterly Journal of Economics 109: 149-182.

[26] Hines, J.R. 1999. "Lessons from Behavioral Responses to International Taxation." National Tax Journal LII(2): 305-322.

[27] Huizinga, H., and L. Laeven. 2007. "International Profit Shifting within European Multinationals." Centre for Economic Policy Research Discussion Paper No. 6048, London, UK.

[28] Huizinga, H., and S.B. Nielsen. 2002. "The coordination of capital income and profit taxation with cross- ownership of firms." Regional Science and Urban Economics $32(1): 1-26$.

[29] Janeba, E. and W. Peters. 1999. "Tax Evasion, Tax Competition and the Gains From Nondiscrimination: the Case of Interest Taxation in Europe." The Economic Journal 109 (452): 93-101.

[30] Janeba, E., and M. Smart. 2003. "Is targeted tax competition less harmful than its remedies?" International Tax and Public Finance 10, (3): 259-280.

[31] Bucovetsky, S. und A. Haufler 2006. "Preferential tax regimes with asymmetric countries." CESifo Working Paper Series 1846, CESifo Group Munich.

[32] Keen, M. 1993. "The Welfare Economics of Tax Co-Ordination in the European Community: A Survey." Fiscal Studies 14(2): 15-36.

[33] Keen, M. 2001. "Preferential Regimes Can Make Tax Competition Less Harmful." National Tax Journal 54 (4): 757-770

[34] Kind, H.J., K.H. Midelfart Knarvik, and G. Schjelderup. 2005. "Corporate Taxation, Multinational Enterprises, and Economic Integration." Journal of International Economics 65: 507-521. 
[35] King, I., R.P. McAfee, and L. Welling. 1993. "Industrial Blackmail: Dynamic Tax Competition and Public Investment." Canadian Journal of Economics 26(3): 590608.

[36] OECD. 1998. Harmful Tax Competition: An Emerging Global Issue. Paris: Organization for Economic Cooperation and Development.

[37] Oman, C.P. 2001. "The Perils of Competition for Foreign Direct Investment", in Jorge Braga de Macedo and Enrique Iglesias, eds., Foreign Direct Investment Versus Other Flows to Latin America, Development Centre Seminars. Paris: OECD Publishing, pp. 63-84.

[38] Pepall, L., D. Richards, and G. Norman. 2008. "Industrial Organization: Contemporary Theory and Empirical Applications." 4th Edition. Blackwell Publishing.

[39] Peralta, S., X. Wauthy, and T. van Ypersele. 2006. "Should Countries Control International Profit Shifting?" Journal of International Economics 68 (1): 24-37.

[40] Phillips, J.M., and E.P. Goss. 1995. "The Effect of State and Local Taxes on Economic Development: A Meta-Analysis." Southern Economic Journal 62: 320333.

[41] Revelli F. 2005. "On spatial public finance empirics." International Tax and Public Finance 12(4):475-492

[42] Swenson, D. 2001. "Tax Reforms and Evidence of Transfer Pricing." National Tax Journal LIV(1): 7-25.

[43] Vandenbussche, H., and C. Tan. 2005. "The Taxation of Multinationals: Firm Level Evidence for Belgium." LICOS Discussion Paper No. 160/2005, Leuven, Belgium. 